\title{
Low-level Electrochemical Analysis of Ketoconazole by Sepiolite Nanoparticles Modified Sensor in Shampoo Sample
}

\author{
Sevda Aydar, ${ }^{1}$ Dilek Eskiköy Bayraktepe, ${ }^{2}$ Hayati Filik ${ }^{1}$ and Zehra Yazan ${ }^{2, *}$ \\ ${ }^{1}$ Faculty of Engineering, Department of Chemistry, Istanbul University, 34320 Avclar, Istanbul, Turkey \\ ${ }^{2}$ Ankara University, Faculty of Science, Chemistry Department, 06560 Ankara, Turkey \\ *Corresponding author: E-mail: zehrayazan67@gmail.com; zdurmus@science.ankara.edu.tr \\ Phone: +903122126720/1284 fax: +903122232395
}

Received: 07-11-2019

\begin{abstract}
In this study, the nano-sepiolite modified carbon paste electrode (CCPE) was prepared for the determination of ketoconazole (KC). The effects of $\mathrm{pH}$, the proportion of the electrode modifier, deposition potential, and deposition time were investigated. Ketoconazole shows one irreversible oxidation peak at about the potential value of $0.6-0.7 \mathrm{~V}$ at different $\mathrm{pH}$ values. $\mathrm{CV}$ studies show that the modified electrode performed a catalytic effect on the peak signal of $\mathrm{KC}$ compared to the bare electrode. This catalytic behavior of CCPE was used for the development of a sensitive detection method. The impact of $\mathrm{pH}$ and scan rates on the anodic peak potentials and currents were examined, and the scan rate results show that the oxidation behavior of $\mathrm{KC}$ was controlled by the adsorption process at the CCPE surface. Therefore, adsorptive stripping differential pulse voltammetry (AdsDPV) and adsorptive stripping square wave voltammetry (AdsSWV) methods were developed for KC analysis. The two different linear ranges were obtained as $(0.1-1.0) \mathrm{nM}$ and (3.0-10.0) nM for AdsDPV, and (0.1-10.0) nM and (3.0-10.0) nM for AdsSWV, respectively. The detection (LOD) and quantification (LOQ) limits were found to be $0.017 \mathrm{nM}$ and $0.056 \mathrm{nM}$ for AdsDPV and $0.025 \mathrm{nM}$ and $0.083 \mathrm{nM}$ for AdsSWV, respectively. Besides, the proposed new sensor has obtained very high recovery values in the analysis of KC in the pharmaceutical shampoo.
\end{abstract}

Keywords: Ketoconazole; carbon paste electrode; sepiolite clay; pharmaceutical shampoo

\section{Introduction}

Ketoconazole is 1 -acetyl-4-[4-[[2RS,4SR)-2-(2,4-dichlorophenyl)-2-(1-H-imidazol-1-yl methyl)-1,3-dioxalan-4-yl] methoxy] phenyl] piperazine and an imidazole derivative. ${ }^{1}$ Ketoconazole (KC) has a strong antifungal effect against many fungal, gram-positive microorganisms and yeasts. In addition, $\mathrm{KC}$ is used in oral administration as an antifungal drug due to its lower toxicity than most azole antimycotics. ${ }^{2}$ The mechanism of action is caused by damage to the cytoplasmic membrane in the fungus and leads to the disruption of mitochondrial and microsomal enzymes of fungi. $\mathrm{KC}$ is used as an active component of antifungal formulations in creams, tablets, and anti-dandruff shampoos. ${ }^{3}$ $\mathrm{KC}$ can cause side effects such as urticaria, angioedema, leukopenia, hemolytic anemia, nausea, and thrombocytopenia.

Determination of ketoconazole due to its importance in biological fluids, pharmaceutical preparations, and also cosmetic products appears to be worthwhile. Various methods have been developed for this purpose, including spectrophotometry, ${ }^{4-7}$ high-performance liquid chromatography, ${ }^{8-10}$ and liquid chromatography-triple quadrupole tandem mass spectrometry. ${ }^{11}$ These methods are often time-consuming and require expensive equipment. Also, due to their low sensitivity, requiring pretreatment steps, such as extraction and separation steps are needed in an organic environment. Electrochemical methods can be considered for the detection of pharmaceutical and cosmetic drugs. Among them, adsorptive stripping voltammetry-based adsorption phenomena can be preferred for the electrochemical detection of pharmaceutical and cosmetic drugs in the terms of sensitivity, trace level analysis, and simplicity. ${ }^{12-15}$ Modification of electrode with nano-materials can be used for developing electrochemical nano-sensors. ${ }^{16,17}$ Electrode modification can 
catalyze the electron transfer rate between the analyte and electrode. Sepiolite clay used as electrode modifier has ease of adsorption for the polar organic species and ions, imparts the electrical conductivity, and has a catalytic contribution to the electrochemical processes. As well, the intercalation and ion exchange capacity of sepiolite clay expands the sorption capacity and conductivity properties of the working electrodes. ${ }^{18,19}$

Electrochemical sensors based on nano-sepiolite clay show trace limit of detection, higher effective surface area, conductivity, and adsorption capacity properties. In our previous studies, we have tried the sepiolite mineral alone and combined with other modifiers for inducing novel properties in carbon paste electrodes. ${ }^{12,19-21}$ In this regard, we have developed two different sensitive and selective adsorptive voltammetric stripping methods (AdsDPV and AdsSWV) for the determination of ketoconazole at sepiolite clay modified CPE. The developed methods were successfully applied to the determination of ketoconazole in shampoo samples containing ketoconazole. The developed AdsDPV and AdsSWV methods for determination of $\mathrm{KC}$ in a shampoo sample, compared to the other electroanalytical methods based on $\mathrm{KC}$ analysis in the cosmetic products ${ }^{1,22-24}$ have the widest linear working range and the lowest limit of detection.

\section{Experimental}

\section{1. Reagents and Apparatus}

Sepiolite clay, graphite powder, mineral oil, and all solvents were supplied from Sigma. Ketoconazole was also supplied from Sigma-Aldrich, and other used chemicals were analytical grade and used without a preliminary purification step. The stock solution of $\mathrm{KC}\left(1.0 \cdot 10^{-3} \mathrm{M}\right)$ was prepared by dissolving of $\mathrm{KC}$ in a few drops of $0.1 \mathrm{M} \mathrm{HCl}$ solution and water. The prepared stock solution was stored in the refrigerator at $+4{ }^{\circ} \mathrm{C} .0 .04 \mathrm{M}$ Britton-Robinson buffer was used as the supporting electrolyte.

All electrochemical measurements (CV, SWV, DPV, and EIS) were performed by using CHI 660C (USA, Texas) and C3 cell stand (Bioanalytical Systems, Inc., USA, BASi) with a solid electrode unit. $\mathrm{Ag} / \mathrm{AgCl}$ (in $3.0 \mathrm{M} \mathrm{NaCl}$, BAS MF-2052) as reference electrode and platinum wire (BASi MW-1032) as auxiliary electrode were used for electrochemical measurements. CCPE and CPE sensors were selected as working electrodes. SEM photographs and EDX graphs were recorded by using Carl Zeiss AG, EVO ${ }^{\circledR} 50$ Series.

Before all assays, $\mathrm{pH}$ was measured with a HANNA Instruments HI2211 pH/ORPmeter. Double-distilled water was supplied $m p$ MINIpure system. All assays were carried out at $25^{\circ} \mathrm{C}$.

AdsDPV and AdsSWV methods were used for the electrochemical determination of KC. For AdsDPV method, the device parameters were: amplitude: $0.05 \mathrm{~V}$, pulse width: $0.05 \mathrm{~s}$, sample width: $0.0167 \mathrm{~s}$, pulse period: $0.5 \mathrm{~s}$. For AdsSWV; amplitude: $0.025 \mathrm{~V}$, frequency $20 \mathrm{~Hz}$, potential range: $0.2-0.8 \mathrm{~V}$. For EIS: amplitude: $0.005 \mathrm{~V}$, frequency range: $0.05-10^{5} \mathrm{~Hz}$, and Nyquist plots were recorded under open circuit potential.

\section{2. Sensor Preparation Procedure}

$30 \mathrm{mg}$ of graphite powder and $10 \mu \mathrm{L}$ of mineral oil were mixed in a petri dish with a spatula to prepare CPE. Sepiolite clay and graphite powder were mixed to prepare CCP electrode and then mineral oil $(10 \mu \mathrm{L})$ was added. The mass ratios of the sepiolite clay in the mixture were changed between $3.3-10 \%$. The electrical connection was provided by copper wire. The surface of the prepared sensors was smoothened with a smooth paper. Before each experiment, the surface cleaning process of modified CPE sensors was performed by washing with a water-ethanol mixture (1:1).

\section{3. Analytical Procedure}

$\mathrm{KC}\left(1.0 \cdot 10^{-3} \mathrm{M}\right)$ stock solution was used in all analyses. In all voltammetric methods, supporting electrolyte (0.04 M BR buffer $\mathrm{pH} 9.0$ ) and KC stock solution were added to the electrochemical cell with a total volume of $10.0 \mathrm{~mL}$. The CCPE, reference, and counter electrodes were immersed in the cell. After arranging all the electrode connections, the working solutions were purged with nitrogen gas (99.99\% purity) to remove the oxygen and then the voltammograms were recorded in the potential window of $0.2 \mathrm{~V}-0.9 \mathrm{~V}$ by using AdsDPV and AdsSWV.

\section{4. Shampoo Sample Preparation}

The $0.5 \mathrm{~g}$ of Ketoral shampoo was weighed to produce the desired final concentration of the sample. After that, a few drops of $0.1 \mathrm{M} \mathrm{HCl}$ and a small amount of doubly distilled water were added. Then, the total volume of pure water to $100 \mathrm{~mL}$ was completed, and the solution was prepared to contain $1.9 \cdot 10^{-4} \mathrm{M} \mathrm{KC}$. This mixture was incubated overnight at $4{ }^{\circ} \mathrm{C}$ to complete the dissolution of the KC. Appropriate volumes of the resulting solution were placed in the voltammetric cell containing $10.0 \mathrm{~mL}$ of BR buffer ( $\mathrm{pH}$ 9.0), and voltammograms were recorded.

\section{Results and Discussion}

\section{1. Surface Characterization of CPE and CCPE}

The surface morphological studies of both bare CPE and sepiolite clay modified CPE (CCPE) were carried out using SEM and EDX measurements. The SEM photographs of CPE and CCPE show that the CCPE electrode 
surface has a more porous structure than bare CPE surface (Fig. 1 a,b). Meanwhile, the EDX measurement was performed to confirm the elemental content of the bare CPE and sepiolite modified CPE (Fig.1 c, d). In Fig.1 c, only one peak is seen that belongs to the carbon (C) element in CP electrode and Fig. $1 \mathrm{~d}$ shows four peaks that belong to the carbon $(\mathrm{C})$, oxygen $(\mathrm{O})$, magnesium $(\mathrm{Mg})$, and silicon $(\mathrm{Si})$, respectively. According to EDX plots and SEM measurements of the electrodes, it can be clearly said that sepiolite clay has remained successfully on the CPE surface.

Cyclic voltammetry (CV) and Electrochemical impedance spectroscopy (EIS) measurements were per- formed using $5.0 \mathrm{mM} \mathrm{Fe}(\mathrm{CN})_{6}{ }^{3-} / \mathrm{Fe}(\mathrm{CN})_{6}{ }^{4-}$ in $0.1 \mathrm{M} \mathrm{KCl}$ solution to compare the electrochemical properties of $\mathrm{CPE}$ and CCPE (Fig.2 a, b). According to the obtained CV voltammograms in Fig.2a, the higher anodic and cathodic peak currents and the lower peak separation $\left(\Delta E_{\mathrm{p}}\right)$ values were obtained at the CCPE electrode compared to CPE. Meanwhile, the Nyquist plots of the same electrode surfaces (Fig.2b) show that the charge transfer resistance $\left(R_{c t}\right)$ (about 4000 ohms) of CCPE is smaller than the $\mathrm{R}_{\mathrm{ct}}$ (about $7000 \mathrm{ohms}$ ) of CPE. CV and EIS results confirm that the sepiolite clay on the CPE surface provides an electrocatalytic effect on the electron transfer rate.
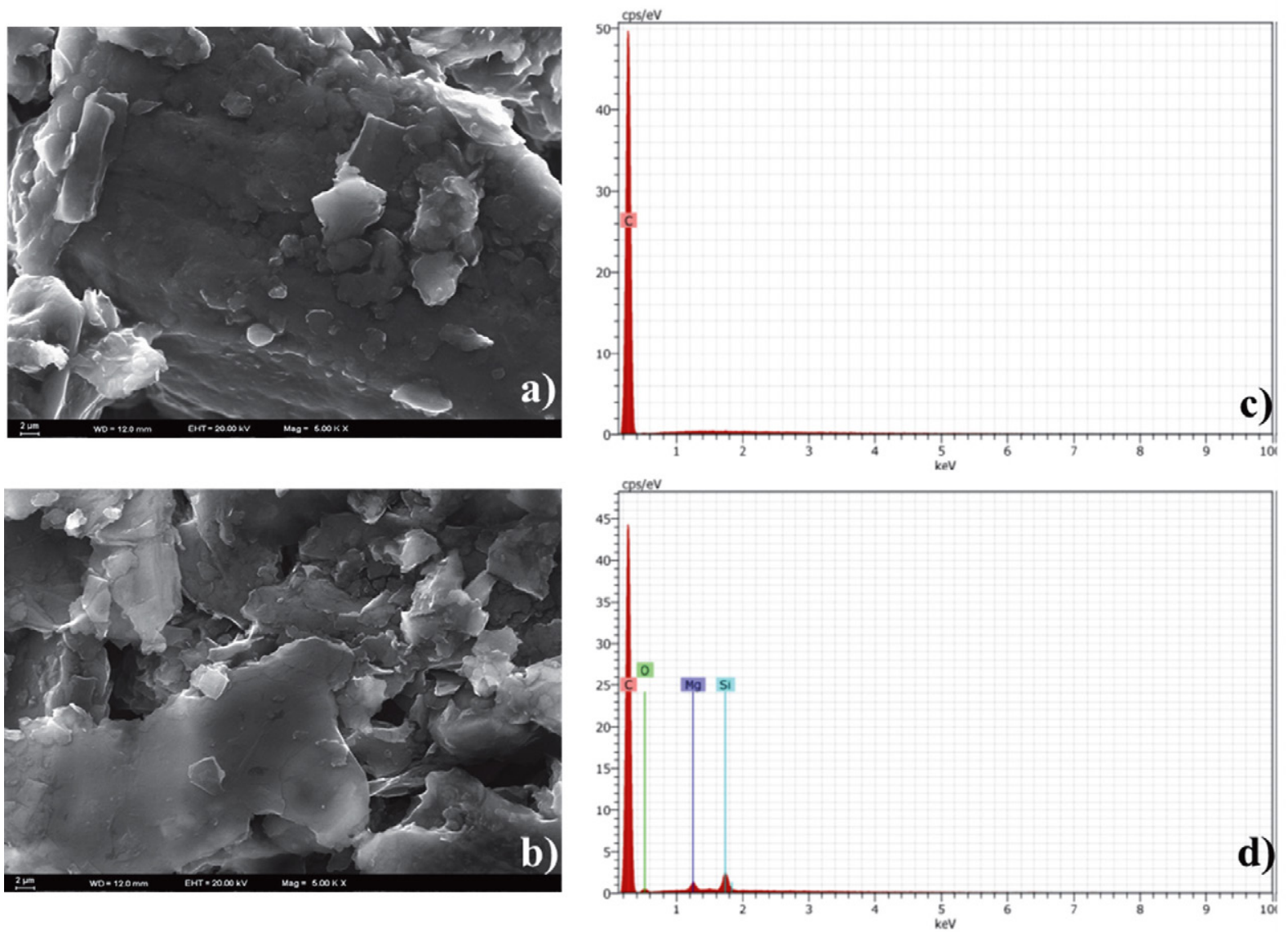

Figure 1. SEM images of CPE (a) and CCPE (b), EDX elemental mapping of CPE (c) and CCPE (d)
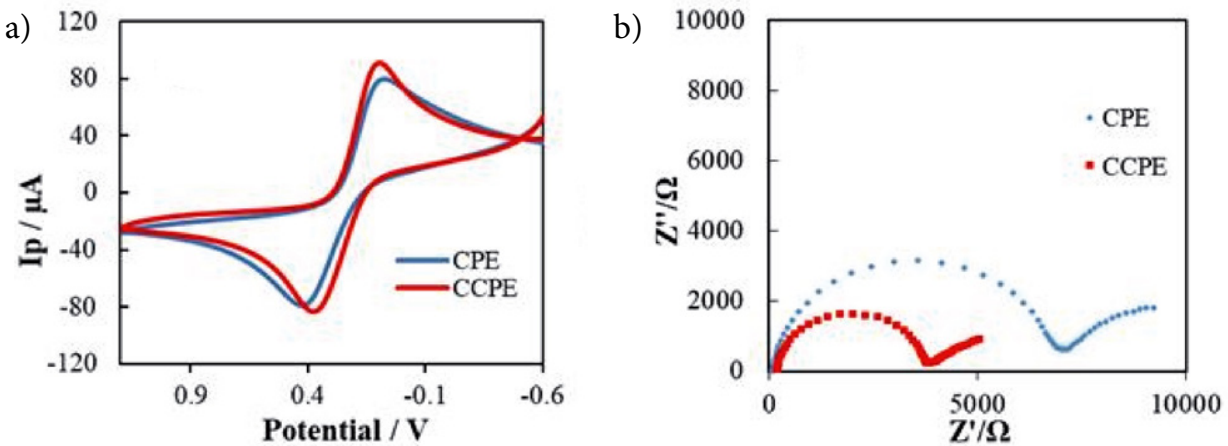

Figure 2. a) $\mathrm{CV}$ voltammograms b) Nyquist plots of $\mathrm{CPE}$ and $\mathrm{CCPE}$ in $5.0 \mathrm{mM} \mathrm{Fe}(\mathrm{CN})_{6}{ }^{3-} / \mathrm{Fe}(\mathrm{CN})_{6}{ }^{4-}$ in $0.1 \mathrm{M} \mathrm{KCl}$ solution. 


\section{2. Optimization of Sepiolite Content}

The optimum amount of sepiolite clay was determined to use in the preparation of the modified CCPE electrode. For this purpose, clay modified electrodes were prepared in such a way that the amount of sepiolite clay was $3.3 \%, 5.0 \%, 6.7 \%, 8.3 \%$, and $10.0 \%$. The signals were recorded using the CV method at a scan rate of $0.1 \mathrm{~V} / \mathrm{s}$ in a BR buffer solution. The peak current of $\mathrm{KC}$ increased up to $6.7 \%$ and decreased sharply at the higher amount of sepiolite (Fig. 3). It indicates that $6.7 \%$ was the optimum amount of sepiolite concentration. The electrode based on nano-sepiolite clay shows the higher peak current as compared to bare CPE because of the high conductivity and catalytic effect to the electron-transfer rate of sepiolite clay. ${ }^{20}$

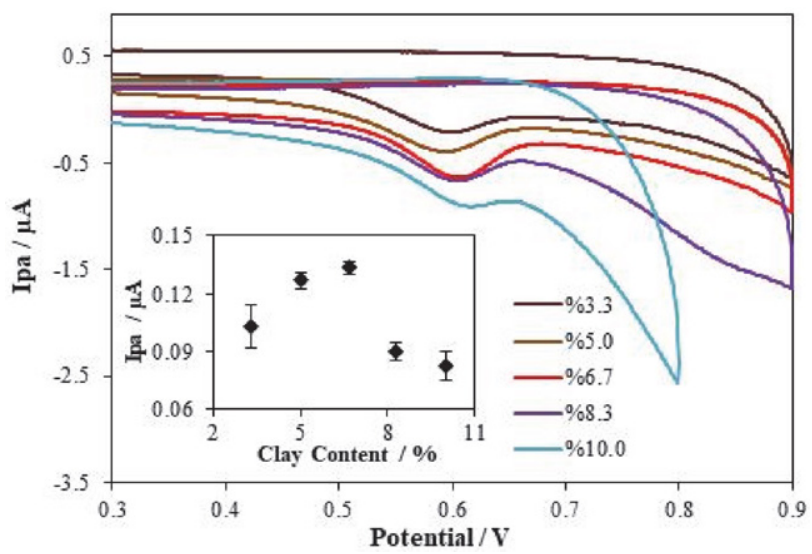

Figure 3. CVs of $1.0 \mu \mathrm{M} \mathrm{KC}$ in BR buffer solution on CCPE with different quantities of sepiolite clay ( $\mathrm{pH} 9.0$; scan rate: $0.10 \mathrm{~V} / \mathrm{s}$ ).

\section{3. Electrochemical Behavior of $\mathrm{KC}$}

The cyclic voltammograms of $1.0 \mu \mathrm{M}$ KC demonstrated the oxidation signals of $\mathrm{KC}$ at $0.597 \mathrm{~V}$ and $0.582 \mathrm{~V}$ potentials at CPE and CCPE electrodes in BR buffer solution ( $\mathrm{pH}$ 9.0), respectively (Fig. 4). The CCPE sensor produced a better current response and sharper peak shapes compared to the bare electrode. The presence of sepiolite clay in the modified electrode improved the sensitivity of the method and the electro-catalytic effect on the redox signals of $\mathrm{KC}$.

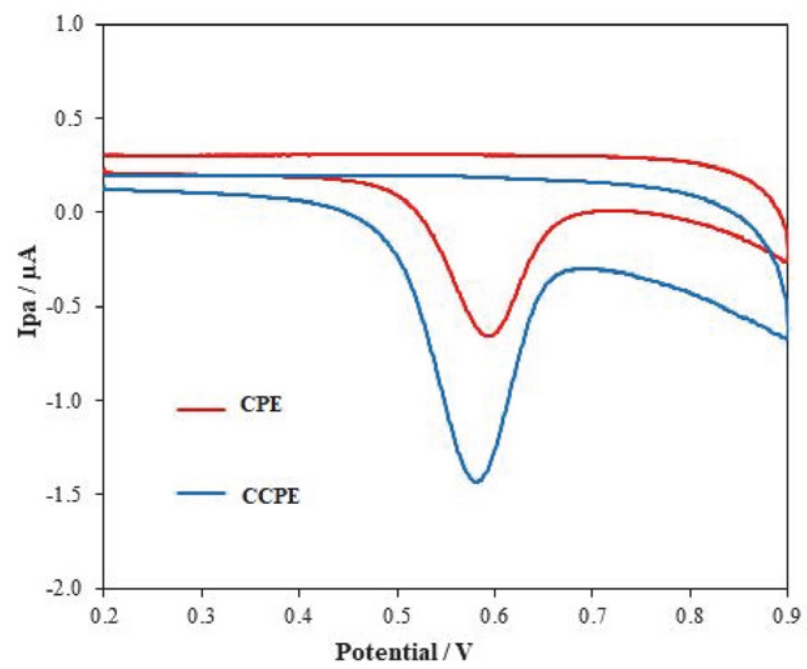

Figure 4. CVs of $1.0 \mu \mathrm{M} \mathrm{KC}$ at $\mathrm{CPE}$ and CCPE electrodes (v: 0.1 $\mathrm{V} / \mathrm{s}, 0.04 \mathrm{M}$ BR buffer, $\mathrm{pH} 9.0$ ).

\section{4. Cyclic Voltammetric Studies}

The effect of the scan rate on the redox properties of $\mathrm{KC}$ was investigated by using the $\mathrm{CV}$ method. For this purpose, cyclic voltammograms were recorded at scan rates in the range $0.005-0.4 \mathrm{~V} / \mathrm{s}$ in the presence of $1.0 \cdot 10^{-6} \mathrm{M} \mathrm{KC}$ on scanning from $0.2 \mathrm{~V}$ to $0.9 \mathrm{~V}$ towards positive potential region on CCPE electrode (Fig. 5). These voltammograms were used for determining whether the electrochemical ox-



Figure 5. CVs of $1.0 \mu \mathrm{M} \mathrm{KC}$ with increasing scan rates in $\mathrm{BR}$ buffer at $\mathrm{pH} 9.0$. Insets: $\operatorname{logv}$ - $\operatorname{logi}{ }_{p}$ graph. 
idation behaviors are reversible, irreversible, or quasi-reversible. As shown in Fig. 5, only one anodic peak at about $0.60 \mathrm{~V}$ was observed. No peak was observed in the reverse scan potentials. In addition, as the scan rate increased, the oxidation signal of $\mathrm{KC}$ is shifted to more positive potential values, and this phenomenon shows that the oxidation peak of KC exhibits irreversible redox behavior. ${ }^{3}$

To monitor the electrochemical process (adsorption or diffusion-controlled) of $\mathrm{KC}$, we used $\mathrm{CV}$ technique. In this context, the $\log i_{p}-\log v$ graph was plotted, and the slope value of the $\log i_{p}-\log v$ graph is 0.78 for the oxidation peak of KC. According to this result, it can be said that the adsorption phenomenon is dominant in the electrochemical behavior of ketoconazole., ${ }^{2,22}$ The fact that pre- or postpeaks are observed in the cyclic voltammograms of $\mathrm{KC}$ at high scan rates is another indication that adsorption does occur on the electrode surface. $\mathrm{I}_{\mathrm{p}}$ vs. $v^{1 / 2}$ graph is nonlinear, which indicates electrochemical reaction is not diffusion controlled.

\section{5. Influence of $\mathrm{pH}$}

The $\mathrm{pH}$ is a crucial parameter that can affect the peak currents and redox mechanism at the electrode surface in voltammetry. Therefore, the effect of $\mathrm{pH}$ on the peak current of $\mathrm{KC}$ was investigated by using the $\mathrm{CV}$ method. The oxidation peak currents of $1.0 \cdot 10^{-6} \mathrm{M} \mathrm{KC}$ were measured at different $\mathrm{pH}(2.0-12.0)$ to determine the optimum $\mathrm{pH}$. Fig. 6. shows that the highest peak current was obtained at $\mathrm{pH}$ 9.0. This $\mathrm{pH}$ value was chosen to perform the electroanalytical study. To investigate the transferred electron number (n) in the electrooxidation of $\mathrm{KC}$ for the irreversible process, we used the following Eq. (1). ${ }^{25}$

$$
E p a-E p a / 2=\frac{47.7}{\alpha n}
$$

Here, $\mathrm{E} p_{\mathrm{a}}$ is anodic peak potential, $\mathrm{E} p_{\mathrm{a}} / 2$ is the half peak potential, $\alpha$ is the electron transfer coefficient. The $\alpha$ is taken to be 0.5 for an irreversible process. In this study, the number of electrons transferred (n) was found to be 2.28. This result is in good accordance with the previously estimated number of electrons of $\mathrm{KC}$ at $\mathrm{pH} 9.0 .{ }^{26}$ Therefore, the oxidation process of $\mathrm{KC}$ involves a two-electron transfer process, and the tentative oxidation peak of $\mathrm{KC}$ was attributed to the oxidation of the imidazole group with the loss of electrons to form the ketone structure. ${ }^{26}$

\section{6. Optimization of Experimental Conditions for AdsDPV and AdsSWV Methods}

Experimental conditions such as deposition potential and time are vital parameters affected by the electrochemical signal of organic compounds. For this purpose, deposition potentials were changed in the range $0.0-1.0 \mathrm{~V}$ for AdsDPV and AdsSWV methods (Fig. 7 A, C). This study has shown that $0.1 \mathrm{~V}$ and $0.4 \mathrm{~V}$ provided the highest peak current for AdsDPV and AdsSWV, respectively. Therefore, these deposition potentials were used in all subsequent experiments.

Similar trials for deposition time were evaluated in deposition time ranging from 0.0 to $180 \mathrm{~s}$ (keeping deposition potentials) (Fig. $7 \mathrm{~B}, \mathrm{D})$. It was observed that $I_{\mathrm{p}}$ values increase rapidly until $75 \mathrm{~s}$, and then they decrease rapidly for AdsDPV method (Fig. 7B). The optimum value of deposition time was chosen as $75 \mathrm{~s}$. Similarly, the deposition time where the highest peak current was observed was selected as $45 \mathrm{~s}$ for AdsSWV (Fig. 7D).

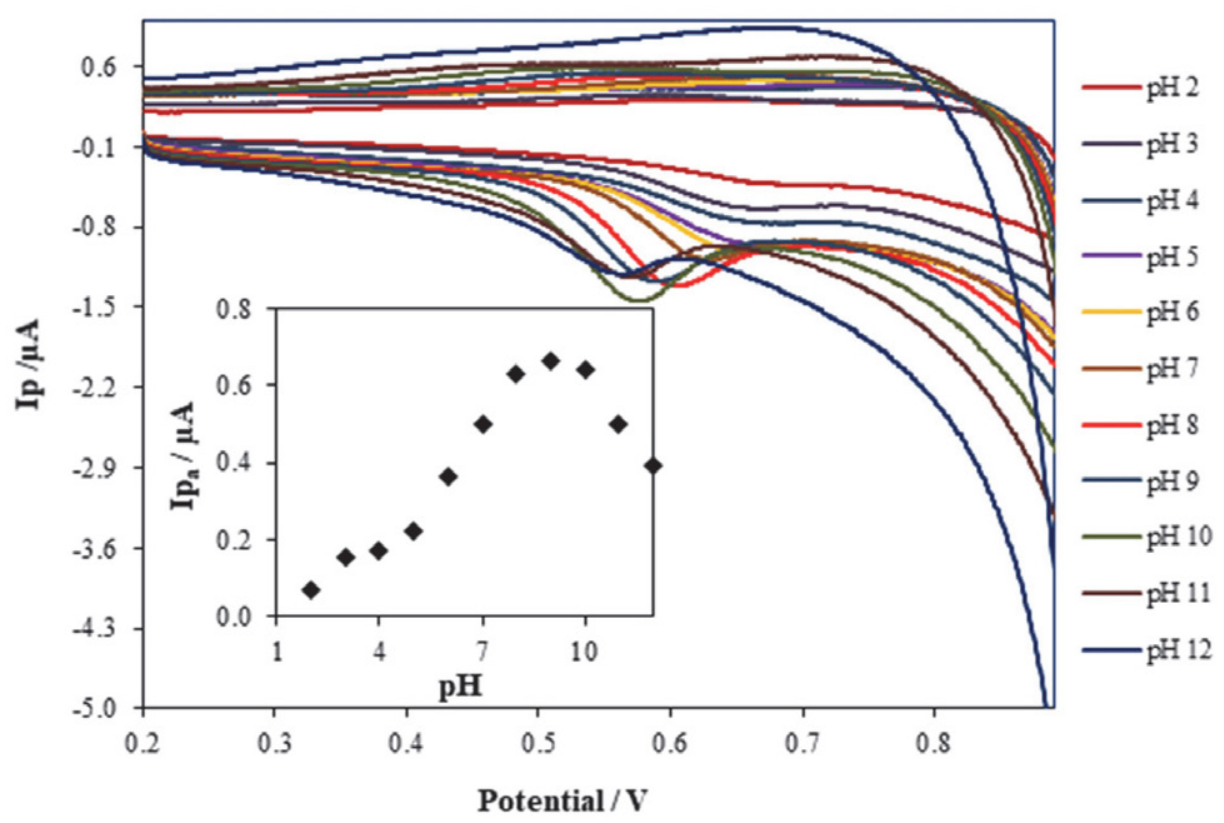

Figure 6. CVs of $1.0 \mu \mathrm{M} \mathrm{KC}$ in different $\mathrm{pH}$ values Inset: $\mathrm{pH}-\mathrm{i}_{\mathrm{p}}$ graph. 

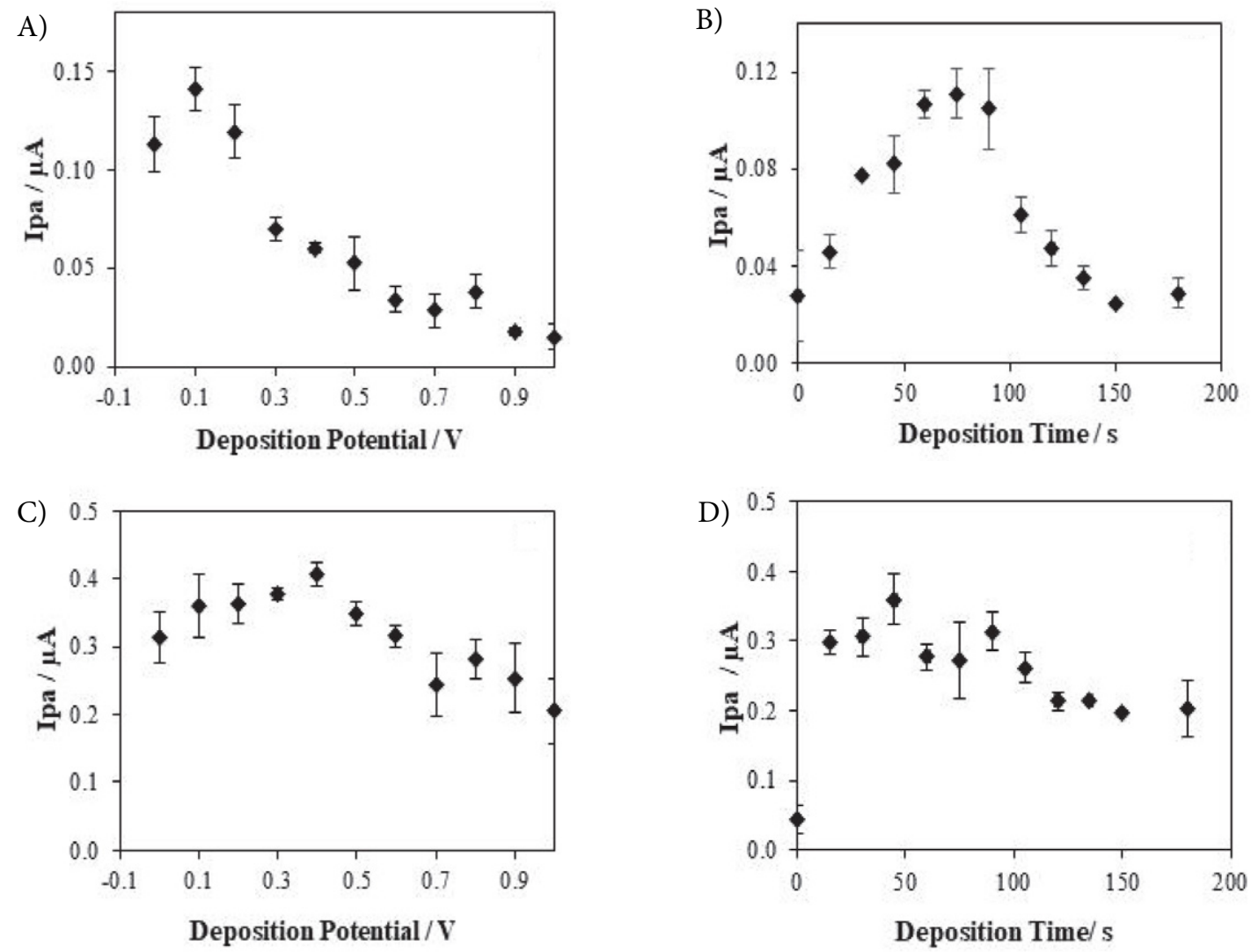

Figure 7. Effect of deposition potential and deposition time on peak current shown in AdsDPV method (A, B) and AdsSVW method (C, D) recorded in the presence of $1.0 \cdot 10^{-7} \mathrm{M} \mathrm{KC}$ at CCPE electrode in $0.04 \mathrm{M}$ BR buffer $\mathrm{pH}$ 9.0.

\section{7. Calibration Studies and Validation of Optimized Methods}

The applicability of AdsDPV and AdsSWV techniques as analytical methods for the analysis of $\mathrm{KC}$ was studied by measuring the anodic current as a function of the KC concentration. Calibration curves were constructed for both methods at $\mathrm{pH}$ 9.0. Considering the slopes of calibration graphs, the results obtained AdsDPV is more sensitive than by AdsSWV (Fig. 8A-B and Table 1). It was decided that the CCPE electrode could determine $\mathrm{KC}$ in the two different linear concentrations ranges of 0.1-1.0 $\mathrm{nM}$ and 3.0-10.0 nM for the AdsDPV and AdsSWV methods.

The following equations calculated the LOD and LOQ values:

$$
\mathrm{LOD}=\frac{3 s}{m} \quad, \quad \mathrm{LOQ}=\frac{10 s}{m}
$$

Where, $s$ is the standard deviation for the studied KC concentration $\left(1.0 \cdot 10^{-9} \mathrm{M}\right)$, and $\mathrm{m}$ is the slope of the calibration chart.

The LOD and LOQ values for AdsDPV were 0.017 $\mathrm{nM}$ and $0.056 \mathrm{nM}$; the AdsSWV was $0.025 \mathrm{nM}$ and 0.083 $\mathrm{nM}$ respectively (Table 1). A survey of the literature reveals that LOD and LOQ values of KC are the lowest results so far.

AdsDPV and AdsSWV methods developed for KC determination on the CCPE electrode were compared to the results obtained by voltammetric methods in the literature (Table 2). The linear working range, LOD, and LOQ values obtained by the CCPE electrode were found to be superior to those reported methods.

The repeatability, reproducibility, and stability of the modified electrode were investigated. Reproducibility of peak current and potential values (intra-day and inter-day) were determined by using AdsSWV and AdsDPV methods. The percentage of relative standard deviation (\%RSD) values is shown in Table 1. \%RSD values are less than $5.0 \%$. These results indicate excellent repeatability. However, the reproducibility of the CCPE sensor was tested using five different electrodes prepared on the same day. The \%RSD values of reproducibility were calculated as $2.58 \%$ and 4.62\% for AdsSWV and AdsDPV, respectively.

To investigate the stability of the CCPE sensor, we recorded the KC signals on different days. After the first ten days, it was found that the sensor signal retains $98.42 \%$ and $99.02 \%$ of the initial value. When the current and potential values of $\mathrm{C}$ oxidation signal obtained up to 40 days were examined, it was observed that peak current and potential values of $\mathrm{KC}$ decreased by $5.0 \%$ compared to its 
A)



B)



Figure 8. A. AdsDPV and B. AdsSWV voltammograms recorded in $0.04 \mathrm{M}$ BR buffer (pH 9.0) for increasing KC concentrations under optimized conditions. Inset: Calibration graphs for KC.

Table 1. The statistical results of the regression analysis obtained with AdsSWV and AdsDPV methods at the CCPE electrode.

\begin{tabular}{|c|c|c|}
\hline \multirow[b]{2}{*}{ Regression parameters } & \multicolumn{2}{|c|}{ CCPE } \\
\hline & AdsSWV & AdsDPV \\
\hline Potential, V & 0.58 & 0.52 \\
\hline Linear working range, $\mathrm{nM}$ & $\begin{array}{c}0.1-1.0 \\
3.0-10.0\end{array}$ & $\begin{array}{c}0.1-1.0 \\
3.0-10.0\end{array}$ \\
\hline The slope of calibration graph, $\mu \mathrm{A} / \mu \mathrm{M}$ & $\begin{array}{c}27.51 \\
4.35\end{array}$ & $\begin{array}{c}49.47 \\
6.75\end{array}$ \\
\hline The intercept of calibration graph, $\mu \mathrm{A}$ & $\begin{array}{l}0.011 \\
0.036\end{array}$ & $\begin{array}{l}0.018 \\
0.060\end{array}$ \\
\hline $\begin{array}{l}\text { Limit of detection (LOD), } \mathrm{nM} \\
\text { Limit of quantification (LOQ), } \mathrm{nM}\end{array}$ & $\begin{array}{l}0.025 \\
0.083\end{array}$ & $\begin{array}{l}0.017 \\
0.056\end{array}$ \\
\hline Regression coefficient $\left(\mathrm{R}^{2}\right)$ & $\begin{array}{l}0.997 \\
0.991\end{array}$ & $\begin{array}{l}0.992 \\
0.993\end{array}$ \\
\hline Repeatability of peak potential, RSD ${ }^{\star} \%$ (intra-day) & 0.76 & 0.68 \\
\hline Repeatability of peak potential, RSD $\%$ (inter-day) & 3.22 & 3.72 \\
\hline Repeatability of peak current, RSD ${ }^{\star} \%$ (intra-day) & 4.51 & 4.63 \\
\hline Repeatability of peak current, $\mathrm{RSD}^{\star} \%$ (inter-day) & 4.44 & 4.04 \\
\hline Reproducibility of peak current, $\mathrm{RSD}^{\star} \%$ & 2.58 & 4.62 \\
\hline Reproducibility of peak potential, $\mathrm{RSD}^{\star} \%$ & 0.83 & 0.82 \\
\hline
\end{tabular}

${ }^{*} \mathrm{RSD}$ is the relative standard deviation of 5 replications. 
Table 2. The comparison of analytical data reported by some different electrochemical sensors with the CCPE sensor for KC analysis.

\begin{tabular}{|c|c|c|c|c|c|}
\hline Sensor & Technique & $\begin{array}{l}\text { Linearity } \\
\text { range } \mu \mathrm{M}\end{array}$ & $\begin{array}{c}\text { LOD } \\
\mu \mathrm{M}\end{array}$ & Application & Reference \\
\hline BDD & SWV & $0.287-3.13$ & 0.0829 & Tablet & 3 \\
\hline CDMGC & DPV & $10.0-80.0$ & 0.105 & Shampoo & 1 \\
\hline CPE & DPV & $0.024-0.48$ & 0.0233 & Tablet, Cream & 22 \\
\hline GCE & DPV & $0.0001-1.0$ & 0.00004 & Tablet & 27 \\
\hline Au disc electrode & DPV & $50.0-2500$ & 50.0 & Tablet, Cream & 23 \\
\hline AuNP/GCE & & $20.0-100.0$ & 2.3 & Shampoo & 24 \\
\hline AuNPs/CPE & DPV, SWV & $1.0-80.0$ & 0.1 & Tablet & 26 \\
\hline \multirow[t]{2}{*}{ CCPE } & AdsDPV & $\begin{array}{c}0.0001-0.001 \\
0.003-0.01\end{array}$ & $0.0168 \mathrm{nM}$ & Shampoo & This paper \\
\hline & AdsSWV & $\begin{array}{c}0.0001-0.001 \\
0.003-0.01\end{array}$ & $0.0248 \mathrm{nM}$ & & \\
\hline
\end{tabular}

BDD: boron-doped diamond electrode; CDMGC: beta-cyclo-dextrin modified glassy carbon electrode; CPE: Carbon paste electrode; GCE: Glassy carbon electrode; AuNPs/GCE: Au nanoparticles modified glassy carbon electrode; AuNPs/CPE: Au nanoparticles modified carbon paste electrode

original values. According to this result, it can be said that the stability of the prepared clay CPE electrode is maintained for up to 40 days. The prepared sensor was kept at + $4{ }^{\circ} \mathrm{C}$ after all experiments.

\section{8. Interferences}

The interference effect of some electroactive species, which can be found in cream and drug substances, has been investigated in voltammetric AdsDPV and AdsSWV methods developed for the determination of KC. For this purpose, the concentration of $\mathrm{Na}^{+}, \mathrm{Mg}^{2+}, \mathrm{K}^{+}, \mathrm{Co}^{2+}, \mathrm{Fe}^{3+}, \mathrm{Cu}^{2+}, \mathrm{Zn}^{2+}$, ascorbic acid, glucose, lactose, glycerin, and sodium benzoate was added to 100 times the concentration of KC. The percent changes in the peak current of $\mathrm{KC}$ in the presence of $\mathrm{Na}^{+}, \mathrm{K}^{+}, \mathrm{Fe}^{3+}$, ascorbic acid, glucose, lactose, glycerin, and sodium benzoate was found to be less than $5 \%$ compared to its original signal. The obtained results indicate that these species did not have any interference effect. The results obtained in the presence of $\mathrm{Mg}^{2+}, \mathrm{Co}^{2+}, \mathrm{Cu}^{2+}$, and $\mathrm{Zn}^{2+}$ showed that these species had a high interference effect in the electrochemical determination of $\mathrm{KC}$. When these cations were added in the presence of $\mathrm{KC}$, the oxidation peak of $\mathrm{KC}$ was observed to disappear. This result may be attributed to the formation of a complex between these metals and KC. ${ }^{28,29}$

\section{9. Real Sample Analysis and Recovery Studies}

To determine the accuracy of the two methods developed, we performed a recovery study using a shampoo (Ketoral shampoo 2.0\% KC). In Table 3, for AdsSWV and AdsDPV methods, the recovery values were found in the range of $99.5 \%$ to $110.4 \%$ indicating that the accuracy of the methods is really satisfactory.

To evaluate the accuracies and precisions of the two developed AdsDPV and AdsSWV methods, student $t$-test and $F$-test were applied to the data obtained from the recovery study. The results show that (Table 3 ) there are no meaningful differences in terms of accuracy and precision between these two methods.

\section{Conclusions}

This study demonstrates that the sepiolite clay modified carbon paste electrode was tested as a sensor for ketoconazole analysis. The ultra-sensitive detection of $\mathrm{KC}$ was carried out for the first time by using anodic adsorptive stripping methods. The effect of modifying agent combination, $\mathrm{pH}$, deposition time, and potential values were in-

Table 3. Recovery results for KC in pharmaceutical shampoo $(\mathrm{n}=5)$

\begin{tabular}{|c|c|c|c|c|c|c|c|}
\hline Method & $\begin{array}{c}\text { Added Amount, } \\
\text { nM }\end{array}$ & $\begin{array}{c}\text { Found Amount, } \\
\mathrm{nM}\end{array}$ & Average & $\begin{array}{c}\text { Recovery, } \\
\%\end{array}$ & $\begin{array}{c}\text { RSD, } \\
\%\end{array}$ & $t$-test & $F$-test \\
\hline \multirow[t]{3}{*}{ AdsSWV } & 3.0 & $3.3 ; 3.1 ; 2.3 ; 3.2 ; 3.1$ & $2.98 \pm 0.129$ & 99.5 & 4.3 & \multirow{6}{*}{$\begin{aligned} t_{\mathrm{d} 1^{*}} & =1.80 \\
t_{\mathrm{d} 2^{*}} & =0.57 \\
t_{\mathrm{d}^{*}} & =1.89\end{aligned}$} & \multirow{6}{*}{$\begin{array}{l}F_{\mathrm{d} 1^{*}}=1.50 \\
F_{\mathrm{d} 2^{*}}=3.06 \\
F_{\mathrm{d}^{*}}=2.42\end{array}$} \\
\hline & 5.0 & $5.1 ; 5.4 ; 5.3 ; 5.2 ; 5.0$ & $5.23 \pm 0.188$ & 104.6 & 3.5 & & \\
\hline & 7.0 & $7.2 ; 7.6 ; 8.1 ; 7.3 ; 8.2$ & $7.73 \pm 0.438$ & 110.4 & 5.6 & & \\
\hline \multirow[t]{3}{*}{ AdsDPV } & 3.0 & $3.1 ; 3.2 ; 2.3 ; 3.3 ; 3.1$ & $3.14 \pm 0.155$ & 104.9 & 4.9 & & \\
\hline & 5.0 & $5.2 ; 5.0 ; 5.3 ; 5.4 ; 4.7$ & $5.13 \pm 0.163$ & 102.7 & 3.1 & & \\
\hline & 7.0 & $6.0 ; 7.9 ; 6.8 ; 6.9 ; 7.3$ & $6.96 \pm 0.591$ & 99.42 & 8.4 & & \\
\hline
\end{tabular}

$t_{\mathrm{k}}=2.31(\mathrm{~N}-2=8$ at $95 \%$ confidence level $) ; F_{\mathrm{k}}=6.39\left(\mathrm{~N}_{1}-1=4\right.$ and $\mathrm{N}_{2}-1=4$ at $95 \%$ confidence level $)$

${ }^{*} 1,2$ and 3 represent the data obtained at concentrations of $3.0,5.0$ and $7.0 \mathrm{~nm}$, respectively. 
vestigated for the determination of $\mathrm{KC}$. The electrochemical determination of $\mathrm{KC}$ was successfully developed on the surface-modified electrode in the shampoo sample. No significant interference was found in the analysis of KC except for some cations. The linear working ranges, LOD, and LOQ values obtained by the developed methods were found to be superior to the methods in the literature. The acceptable recovery and low relative standard deviation data demonstrated that the accuracy and precision of the developed methods were satisfactory.

\section{Acknowledgements}

We gratefully acknowledge the financial support provided by Ankara University, Scientific Research Fund (Project number: 17H0430009).

\section{References}

1. M. El Ries, M. A. Ghany, L. Hussin, F. M. El-Anwar and A. Mohamed, Bull. Fac. Pharm. Cairo Univ. 2013, 51, 49-55. DOI:10.1016/j.bfopcu.2011.09.001

2. J. Borowiec, L. Wei, L. Zhu and J. Zhang, Anal. Methods 2012, 4, 444-448. DOI:10.1039/c2ay05615a

3. K. Mielech-Łukasiewicz and K. Rogińska, Anal. Methods 2014, 6, 7912-7922. DOI:10.1039/C4AY01421A

4. S. S. Rane and P. Padmaja, J Pharm Anal 2012, 2, 43-47. DOI:10.1016/j.jpha.2011.10.004

5. É. R. Kedor-Hackmann, M. M. Nery and M. I. R. Santoro, Anal. Lett. 1994, 27, 363-376.

DOI:10.1080/00032719408001079

6. M. P. Vojić, G. Popović, D. Sladić and L. Pfendt, J. Serb. Chem. Soc. 2005, 70, 67-78. DOI:10.2298/JSC0501067V

7. S. Fraihat and K. Bahgat, Trop J Pharm Res. 2014, 13, 15111514. DOI:10.4314/tjpr.v13i9.18

8. O. Popovska, Z. Kavrakovski and V. Rafajlovska, Curr Pharm Anal. 2017, 13, 505-511.

DOI:10.2174/1573412912666160610104703

9. S. H. Kim, A. Shrestha, N. H. Hoang, N. L. Huong and J. W. Park, Anal. Lett. 2014, 47, 1465-1475.

DOI: $10.1080 / 00032719.2013 .874013$

10. D. A. Hamdy and D. R. Brocks, J Pharm Biomed Anal. 2010, 53, 617-622. DOI:10.1016/j.jpba.2010.04.018
11. K. Wang, Y. Wu, Z. Chi, C. Shu, L. Li, J. Wei, L. Tao, P. Ma and L. Ding, J Pharm Biomed Anal. 2016, 128, 504-509. DOI:10.1016/j.jpba.2016.06.025

12. S. Aydar, D. E. Bayraktepe, H. Filik and Z. Yazan, Acta Chim. Slov. 2018, 65, 946-954. DOI:10.17344/acsi.2018.4615

13. P. T. Pinar, Acta Chim. Slov.2020, 67, 212-220. DOI:10.17344/acsi.2019.5367

14. F. Öztürk, I. H. Taşdemir, D. A. Erdoğan, N. Erk, E. Kılıç. Acta Chim. Slov. 2011, 58, 830-839.

15. M. Á. Lorenzo, A. S. Arribas, M. Moreno, E. Bermejo, M. Chicharro and A. Zapardiel, Microchem J. 2013, 110, 510516. DOI:10.1016/j.microc.2013.05.018

16. G. Xu, M. Zhang and X. Yu, Acta Chimica Slovenica 2018, 65, 502-511. DOI:10.17344/acsi.2017.3974

17. T. Dodevska, I. Shterev and Y. Lazarova, Acta Chim. Slov. 2018, 65, 970-979. DOI:10.17344/acsi.2018.4672

18. Z. Navrátilová and P. Kula, Electroanalysis 2003, 15, 837-846. DOI:10.1002/elan.200390103

19. M. Pekin, D. E. Bayraktepe and Z. Yazan, Ionics 2017, 23, 3487-3495. DOI:10.1007/s11581-017-2132-8

20. D. E. Bayraktepe, Z. Yazan and K. Polat, J. Electroanal. Chem. 2016, 780, 38-45. DOI:10.1016/j.jelechem.2016.08.035

21. D. E. Bayraktepe, T. Yanardağ, Z. Yazan and A. Aksüt, Rev. Roum. Chim 2015, 60, 287-295.

22. M.ShamsipurandK.Farhadi,Electroanalysis2000,12,429-433. DOI:10.1002/(SICI)1521-4109(20000401)12:6<429::AIDELAN429>3.0.CO;2-R

23. O. Gładysz, P. Łoś, B. Karolewicz and A. Górniak, Int. J. Electrochem. Sci 2016, 11, 1676-1690.

24. M. M. Alshalalfeh, M. Sohail, T. A. Saleh and M. A. Aziz, Aust. J. Chem. 2016, 69, 1314-1320. DOI:10.1071/CH16072

25. J. Wang, Analytical Electrochemistry, Wiley, New York, 2006. DOI:10.1002/0471790303

26. T. A. Saleh, K. M. AlAqad and A. Rahim, J. Mol. Liq. 2018, 256, 39-48. DOI:10.1016/j.molliq.2018.02.006

27. T. Peng, Q. Cheng and C. F. Yang, Fresenius J. Anal. Chem. 2001, 370, 1082-1086. DOI:10.1007/s002160100773

28. E. Robles-Escajeda, A. Martínez, A. Varela-Ramirez, R. A. Sánchez-Delgado and R. J. Aguilera, Cell Biol Toxicol 2013, 29, 431-443. DOI:10.1007/s10565-013-9264-z

29. M. Navarro, E. J. Cisneros-Fajardo, T. Lehmann, R. A. Sánchez-Delgado, R. Atencio, P. Silva, R. Lira and J. A. Urbina, Inorg. Chem. 2001, 40, 6879-6884.

DOI:10.1021/ic0103087 


\section{Povzetek}

V predstavljeni študiji smo pripravili elektrodo iz ogljikove paste, modificirano z nano-sepiolitom (CCPE) in jo uporabili za določitev ketokonazola (KC). Raziskali smo vpliv pH, deleža elektrodnega modifikatorja, depozicijskega potenciala in časa depozicije. Ketokonazol daje samo en ireverzibilni oksidacijski vrh pri vrednosti potenciala okrog $0,6-0,7 \mathrm{~V}$ pri različnih vrednostih $\mathrm{pH}$. CV študija je pokazala, da modificirana elektroda katalitsko učinkuje na maksimalni signal KC v primerjavi z golo elektrodo. To katalitsko obnašanje CCPE smo uporabili za razvoj občutljive metode detekcije. Raziskali smo vpliv pH in hitrosti preleta na maksimalni anodni potencial in tok. Rezultati za hitrost preleta pokažejo, da je oksidacijsko obnašanje KC kontrolirano s procesom adsorpcije na površino CCPE. Zaradi tega smo za analizo KC razvili metodi adsorpcijske inverzne diferencialne pulzne voltametrije (AdsDPV) in adsorpcijske inverzne pravokwwotno-pulzne voltametrije (AdsSWV). Za AdsDPV smo dobili dve različni linearni območji: $(0,1-1,0) \mathrm{nM}$ in $(3,0-10,0)$ $\mathrm{nM}$, za AdsSWV pa $(0,1-10,0) \mathrm{nM}$ in $(3,0-10,0) \mathrm{nM}$. Meje zaznave (LOD) in meje določitve (LOQ) smo določili kot $0,017 \mathrm{nM}$ in $0,056 \mathrm{nM}$ pri AdsDPV ter $0,025 \mathrm{nM}$ in $0,083 \mathrm{nM}$ pri AdsSWV. Predlagani novi senzor je dosegal zelo visoke izkoristke oz. točnost pri analizi $\mathrm{KC} \mathrm{v}$ farmacevtskem šamponu. 